\title{
Resin matrix ceramics - mechanical, aesthetic and biological properties
}

\section{Cerâmicas de matriz resinosa - propriedades \\ mecânicas, estéticas e biológicas}

\author{
Mariana ALVES DE LUCENA ${ }^{1}$ iD https://orcid.org/0000-0001-7360-3644 \\ Adriano RELVAS' (D) https://orcid.org/0000-0002-4822-9088 \\ Mauro LEFRANÇOIS ${ }^{1}$ iD https://orcid.org/0000-0001-7064-7940 \\ Marcos VENíCIO AZEVEDO1 (iD https://orcid.org/0000-0002-1266-2488 \\ Pablo SOTELO1 (iD https://orcid.org/0000-0001-5212-3297 \\ Laura SOTELO1 (iD https://orcid.org/0000-0003-3398-4408
}

\begin{abstract}
Resin matrix ceramics consist in a polymeric matrix with predominantly inorganic refractory compounds which may include porcelain, glass, ceramics, and glass ceramics, and are divided into three subgroups: Nanoceramics, Vitroceramics, and Zirconia-silica. The aim of this study was to compare, through a literature review, the mechanical and biological properties of resin matrix ceramics, with glass matrix ceramics and polycrystalline ceramics. After reviewing 44 articles found in the US National Library of Medicine (PubMed) database (studies published in English, human clinical studies, in vitro or in vivo studies) that evaluated some properties of this material, such as elasticity modulus, wear resistance, adhesiveness, stain resistance and hardness, this article concluded that, although they belong to the same group, resin matrix ceramics are different from each other due to their microstructures. Moreover, when compared to other ceramic groups, it showed some superior properties, such as flexural strength, fatigue strength and internal adaptation.
\end{abstract}

Indexing terms: Ceramics. Composite resins. Computer-aided design. Resins.

\section{RESUMO}

A cerâmica de matriz resinosa consiste em uma matriz polimérica contendo compostos refratários predominantemente inorgânicos que podem incluir porcelana, vidro, cerâmica e cerâmica vitrea. A cerâmica de matriz resinosa é subdividida em três subgrupos: nanocerâmica, vitrocerâmica e zircônia-sílica. O objetivo deste estudo foi comparar as propriedades mecânicas e biológicas, por meio de uma revisão da literatura, das cerâmicas de matriz resinosa comprando-as com cerâmicas de matriz vitrea e cerâmicas policristalinas. Após revisão de literatura de 44 artigos pesquisados na base de dados da Biblioteca Nacional de Medicina (PUBMED) dos EUA (estudos publicados no idioma inglês, estudos clínicos em humanos, estudos in vitro ou in vivo) que avaliaram algumas propriedades deste material, como módulo de elasticidade, resistência ao desgaste, adesividade, resistência a manchas e dureza, este estudo concluiu

$\boldsymbol{\nabla} \boldsymbol{\nabla} \boldsymbol{\nabla}$

1 Pontifícia Universidade Católica, Faculdade de Odontologia, Departamento de Prótese Dentária. Rua Marquês de São Vicente, 389, Gávea, 22451-041, Rio de Janeiro, RJ, Brasil. Correspondence to: A RELVAS. E-mail: <relvasrj@yahoo.com.br>.

V V V

How to cite this article

Alves de Lucena M, Relvas A, Lefrançois M, Venício Azevedo M, Sotelo P, Sotelo L. Resin matrix ceramics - mechanical, aesthetic and biological properties. RGO, Rev Gaúch Odontol. 2021;69:e20210018. http://dx.doi.org/10.1590/1981-86372021001820190130 
que, embora pertençam ao mesmo grupo, as cerâmicas de matriz resinosa têm características diferentes umas das outras devido às suas diferentes microestruturas. Além disso, quando comparada aos demais grupos cerâmicos, apresentou algumas propriedades superiores, como resistência à flexão, resistência à fadiga e adaptação interna.

Termos de indexação: Cerâmica. Resinas compostas. Desenho assistido por computador. Resinas.

\section{INTRODUCTION}

Launched in the market around 1962, dental composite resins have undergone several changes to improve their properties for having more space in the market. At the same time, scientific investigations on these materials have also expanded [1].

The mechanical properties of different types of composite resins, such as hardness, tensile strength, compression and shear, increase the clinical success of the restorative material [2,3]. These properties are directly related to the polymeric matrix (monomer composition), inorganic filler (type, size and distribution of filler) and bonding agent.

The incorporation of nanoparticles helped to obtain a restorative material capable of being used in all areas, with high initial polishing, superior gloss retention (typical of microparticles), as well as excellent mechanical properties such as wear resistance in areas with high chewing stress (typical of hybrid composites) [4].

On the other hand, dental ceramics are known for their satisfactory and similar properties to natural teeth: translucency, fluorescence, chemical stability, coefficient of linear thermal expansion close to the dental structure, biological compatibility, as well as increased compressive and abrasion resistance [5].

There are three large groups of ceramics divided according to their microstructure. The criteria used to differentiate them are based on the phase or phases present in their chemical composition: glass matrix ceramics (nonmetallic inorganic ceramic materials containing a glass phase); polycrystalline ceramics (non-metallic inorganic ceramic materials without any glass phase); or resin matrix ceramics (polymeric matrix containing predominantly inorganic refractory compounds which may include porcelain, glass, ceramics, and glass ceramics). Resin matrix ceramics are subdivided into three subgroups: Nanoceramics, Vitroceramics, and Zirconia-silica [6].

Compared to ceramics, indirect restorations of resin composites are more flexible, less rigid, have a better finishing and polishing, and are less abrasive to the antagonistic dental element. They are easier to adjust when necessary, but their aesthetic properties are inferior [7]. In addition, ceramics are more wear-resistant, more biocompatible and more resistant to discoloration; however, they are more friable and susceptible to fracture. The purpose of resin matrix ceramics is to combine the positive properties of these two materials [7] in compact blocks ready to be milled, without any physical-chemical alteration that could change their molecular structure and without affecting their mechanical properties.

Thus, the objective of this study was to evaluate, through a literature review, the mechanical and biological properties of resin matrix ceramics and to compare them with glass matrix ceramics and polycrystalline ceramics.

\section{METHODS}

The integrative literature review was performed by a single researcher who started the activities with an electronic search in the US National Library of Medicine (PuBMeD) database.

The term "resin matrix ceramic" were used to select the articles: a total of 162 studies. After reading their titles and abstracts, only 71 studies were selected. Of this total, 27 studies were excluded from the review for not being related to the theme, according to the following inclusion and exclusion criteria:

\section{Inclusion criteria:}

- Studies published in English;

- Human clinical studies;

- In vitro or in vivo studies.

\section{Exclusion criteria:}

- Studies published in a language other than English;

- Case reports;

- Clinical studies in animals.

\section{DISCUSSION}

Resin matrix ceramics are materials with an organic matrix highly filled with ceramic particles. 
The presence of an organic matrix would theoretically exclude resin matrix ceramic materials from the materials classification before 2013. However, the 2013 version of the ADA Code in Dental Procedures and Nomenclature defines the term "porcelain/ceramics" as "pressed, polished, milled or fired materials containing predominantly inorganic refractory compounds including porcelains, glasses, ceramics and glass-ceramics".

Despite the controversies, resin ceramics aim to obtain a material that simulates the elasticity modulus of the dentin and that is more easily adjustable. Currently, these resin matrix ceramic materials can be divided into several subfamilies according to their inorganic composition: resin nanoceramic (Lava Ultimate, 3M ESPE; Cerasmart, GC America); glass ceramic in a resin interpenetrating matrix (Enamic, Vita); zirconia-silica ceramic in a resin interpenetrating matrix (e.g., Paradigm MZ100, 3M ESPE; Shofu Block HC, Shofu) [8].

\section{Mechanical properties}

Several studies comparing the mechanical properties of resin matrix ceramics show different results due to their microstructures. For example [9], the difference between the type of filler in cerasmart (zirconia-silica) gives this material greater hardness and toughness than Lava Ultimate. On the other hand, Lava Ultimate, because of its crystalline content $\left(32 \% \mathrm{ZrO}_{2}\right)$ - compared to the crystalline content (20.6\% $\left.\mathrm{Al}_{2} \mathrm{O}_{3}\right)$ in Enamic -, has higher flexural strength [10-13]. On the other hand, Enamic has the highest elasticity modulus when compared to Lava Ultimate, Cerasmart and Paradigm MZ100 [14]. These materials, when compared to polycrystalline or glass-matrix ceramics, show significantly superior results for flexural strength, fatigue and reliability than restorative feldspar-based and leucite-reinforced CAD/CAM restorative materials [15-17] due to the absorption of chewing forces by the organic content in the resin matrix, greatly increasing the flexural strength of this type of material $[10,18,19]$. However, when compared to lithium disilicate, they show significantly lower mechanical properties [14,20] and lower elasticity modulus [14].

The Weibull modulus of resin matrix ceramic materials were similar [10,21-23] or superior [24] to other types of ceramics, which proves their homogeneity. On the other hand, a lower surface hardness and fracture resistance of resin matrix ceramics were observed, caused by the lower concentration of inorganic load in its microstructure
[20]. This material's characteristic causes less damage to the CAD CAM milling burs during restorations [14,25], with smoother margins due to the ease of milling [16], as well as less enamel wear of the antagonist element $[18,26]$. However, the resilience of these materials in relation to the restorations margins could cause microinfiltrations and damage the cementation line [16].

Even in studies in which resin matrix ceramics have lower mechanical properties, this material group was in accordance with the ISO standard for ceramics (ISO 6872: 2008), revealing considerably higher fracture resistance than the average occlusal force on the posterior dentition, and may show a long term treatment to restore the occlusal surfaces of the posterior teeth $[27,28]$. They are, however, contraindicated in fixed partial dentures [12].

\section{Roughness}

Surface roughness, material thickness and type, and polishing are factors directly related to translucency. Translucency, associated with stain resistance and gloss, may interfere with the aesthetic result of a restoration. Promising results related to the translucency of resin matrix ceramics have been shown in some studies, except for Vita Enamic due to the relatively high amount of $\mathrm{Al}_{2} \mathrm{O}_{3}$ [29]. Samples of this material show significant differences in gloss and stain resistance when polished or unpolished. However, they still have inferior results in relation to lithium disilicate in these aspects.

\section{Wear Resistance}

In addition to mechanical, physical and chemical properties partially detailed by manufacturers, wear resistance is another important property studied by researchers with simulations of contact with human enamel. Although being part of the same ceramic group, the results of Shofu Block HC and Katana Avancia, due to their smaller amount of filler particles, have lower wear resistance when subjected to abrasion and fatigue in comparison to Cerasmart and Brilliant Crios. However, when subjected to hydroabrasive erosion, the size of the filler particles have more influence on the result, which leads Katana Avancia to obtain more promising results [30]. The complex mechanisms of wear in vivo are difficult to reproduce in vitro. When compared to human enamel, 
Lava Ultimate and Vita Enamic had similar characteristics of ceramics and composites, not differing from the enamel behavior in relation to the wear of the material itself and the antagonist [31]. Vita Enamic, for having higher elasticity modulus in comparison to resin matrix ceramic materials, causes greater wear to the antagonist enamel when compared to Lava Ultimate, Paradigm MZ100 and Cerasmart, behaving similarly to lithium disilicate. However, considering the wear of the material itself, there is less wear in Vita Enamic than in lithium disilicate, behaving similarly to other resin ceramics. Feldspar ceramic, due to its vitreous microstructure, has higher wear resistance than Vita Enamic, 3M and Paradigm MZ100 resin matrix ceramics [32]. Nevertheless, in a study on the subject, when compared to cerasmart and Block HC, they showed better results [12]. This same Cerasmart, when compared to lithium disilicate, showed greater wear [30].

\section{Degradation}

When exposed to the oral environment, resin materials show increased roughness [9] which, when greater than $2 \mu \mathrm{m}$, increases the possibility of bacterial deposition, leading to a higher incidence of periodontal disease or caries [33]. Regarding in vitro studies, Cerasmart has greater flexural strength after aging than other resin matrix ceramics, such as Vita Enamic and Lava Ultimate $[21,34]$. In addition to surface roughness [35], the mechanical properties of materials may change due to the degradation of the organic matrix, loss of charge particles [9] and destruction of silane adhesion to charge particles [36], causing a reduction in the flexural strength of resin matrix ceramics [21,34]. The effect of brushing and artificial storage on surface roughness depends on the material and polishing system, with a difference in the behavior of resin matrix ceramics related to their microstructure. While materials such as Amberino High-Class, Lava Ultimate and Paradigm MZ100 have poorer micromechanical properties and behave analogously to composite resins, Vita Enamic acts like feldspar ceramics and are less susceptible to storage and brushing degradation [37]. There is still no consensus in literature regarding the influence of aging on resin matrix ceramics when compared to other materials and to each other concerning color stability. Some studies concluded that resin matrix ceramics have similar [20,21] or clinically similar [35] color stability, whereas other studies found the opposite [10]. When comparing resin matrix ceramics with each other, Lauvauthanon et al. concluded Enamic (86.4\% filler content) is less sensitive to thermocycling than Lava Ultimate (73.1\%) [12], whereas Sonmez et al. - through EDS microanalysis and similar load contents - concluded there is no significant difference when materials are exposed to thermocycling [10]. The lower the amount of inorganic filler of a material, the higher its resin organic matrix responsible for "shock absorption", i.e., greater resistance to cracks and better adhesion, which justifies the better results found for Katana Avencia Blocks and Shofu Block HC when compared to Cerasmart. However, the lower amount of fillers creates a higher risk of lixiviation when exposed to the oral environment [17].

Restorations are subject to load in the presence of moisture, thermal and chemical variation, with average cycles of 500,000 per year [38], and fractures are more likely to occur under subcritical loads when restorations are subject to fatigue. Laboratory tests show that resin matrix ceramics, when compared to polycrystalline and resin matrix ceramics, are less sensitive to fatigue [39].

\section{Adaptation and adhesion}

For a better restoration, it is important to choose a proper prosthesis, with correct surface treatment, and high quality resin cements.

Regarding the adjustment of materials, Alexis et al. [27] described the internal adaptation of polymer-based blocks, comparing them with a lithium disilicate glass-ceramic block. IPS e.max CAD and Cerasmart were considered the best concerning flexural strength and had better internal fit.

Adhesive cementation systems are generally the choice for cementing resin matrix ceramics $[12,40]$. For these materials, adhesiveness is directly related to chemical reactions or mechanical retention, depending on the resin cement composition and the pretreatment of the material surface.

Several studies analyzed surface roughness by either Al2O3 or CoJet/SilJet blasting results in improved adhesion [41-48], although the use of hydrofluoric acid is mentioned as more effectively in some of these studies $[42,43,46,48]$. The use of phosphoric acid which, although not reactive enough to increase the ceramic surface energy, seems to have a cleaning effect, improving adhesion $[47,49,50]$. Since resin matrix ceramics have silanizable 
sites, they may receive application of the silane bonding agent. Moreover, their effectiveness has been widely described in the literature $[42-44,47]$, even though some groups found no effect of silanization $[46,48]$.

In the surface treatment, glass ball abrasion is more effective to increase durability between resin cements and CAD/CAM materials than alumina blasting, ceramic primer [41] or hydrofluoric acid [51]. Resin matrix ceramics differ in their bond strength. The worst results found in Lava Ultimate and Cerasmart are due to the penetration of water into the resin matrix, a fact minimized by the interpenetrating ceramic matrix of Vita Enamic [51].

\section{CONCLUSION}

Although belonging to the same group, resin matrix ceramics show different characteristics due to their microstructures. These nanoceramic resins have greater flexural and wear resistance; glass ceramics embedded in resin matrix have higher elasticity modulus, lower translucency, generate more wear on the antagonist enamel and are less subject to degradation by storage; and silica zirconia ceramics are better in terms of hardness and toughness.

When compared to other types of ceramics, resin matrix ceramics were less sensitive to fatigue, had higher flexural strength, greater or similar reliability, lower elasticity modulus, lower gloss and stain resistance, lower surface hardness, higher internal adaptation, and were more susceptible to fracture.

To achieve better adhesive resistance, glass ball abrasion is the gold standard for conditioning.

\section{Collaborators}

M ALVES DE LUCENA, funding acquisition, investigation, methodology, resources and writing-original draft. A RELVAS, methodology, resources, software and writing-original draft. M LEFRANÇOIS, M VENÍCIO AZEVEDO and P SOTELO, resources and writing-original draft. L SOTELO, supervision and writing-review \& editing.

\section{REFERENCES}

1. Yap AUJ, Yap SH, Teo CK, Ng JJ. Finishing/polishing of composite and compomer restoratives: effectiveness of onestep systems. Oper Dent-Univ Wash. 2004;29:275-279.
2. Miranda DDA, Bertoldo CEDS, Aguiar FHB, Lima DANL, Lovadino JR. Effects of mouthwashes on Knoop hardness and surface roughness of dental composites after different immersion times. Braz Oral Res. 2011;25(2):168-173. https:// doi.org/10.1590/s1678-77572012000200013

3. Gordan VV, Patel SB, Barrett AA, Shen C. Effect of surface finishing and storage media on bi-axial flexure strength and microhardness of resin-based composite. Oper Dent-Univ Wash. 2003;28(5):560-567.

4. Firoozmand LM, Araujo RM, Balducci, I. Influência de fotopolimerizadores de luz halogena $X$ led azul na dureza de resina composta. Braz Dent Sci. 2005;8(1). https://doi. org/10.14295/bds.2005.v8i1.234

5. Garcia LDFR, Consani S, Cruz PC, Souza FDCPP. Análise crítica do histórico e desenvolvimento das cerâmicas odontológicas. RGO, Rev Gaúch Odontol. 2011;59:67-73.

6. Gracis S, Thompson VP, Ferencz JL, Silva NR, Bonfante EA. A new classification system for all-ceramic and ceramic-like restorative materials. Int J Prostodont. 2015;28(3). https://doi. org/10.11607/ijp.4244

7. Lim HN, Yu B, Lee YK. Spectroradiometric and spectrophotometric translucency of ceramic materials. J Prost Dent. 2010;104(4):239-246. https://doi.org/10.1016/S00223913(10)60131-X

8. Lawson NC, Burgess JO. Gloss and stain resistance of ceramic polymer CAD/CAM restorative blocks. J Esthet Restor Dent. 2016;28: S40-S45. https://doi.org/10.1111/jerd.12166

9. Minami H, Hori S, Kurashige $H$, Murahara S, Muraguchi $K$, Minesaki $Y$, et al. Effects of thermal cycling on surface texture of restorative composite materials. Dent Mater J. 2007; 26(3):316-322. https://doi.org/10.4012/dmj. 26.316

10. Sonmez N, Gultekin P, Turp V, Akgungor G, Sen D, Mijiritsky E. Evaluation of five CAD/CAM materials by microstructural characterization and mechanical tests: a comparative in vitro study. BMC Oral Health. 2018;18(1):5. https://doi.org/10.1186/ s12903-017-0458-2

11. Ruse ND, Sadoun MJ. Resin-composite blocks for dental CAD/ CAM applications. J Dent Res. 2014;93(12):1232-4. https:// doi.org//10.1177/0022034514553976

12. Lauvahutanon S, Takahashi H, Shiozawa M, Iwasaki N, Asakawa Y, Oki M, et al. Mechanical properties of composite resin blocks for CAD/CAM. Dent Mater J. 2014;33:705-10. https://doi.org/10.4012/dmj.2014-208

13. Sen N, Us YO. Mechanical and optical properties of monolithic CAD-CAM restorative materials. J Prosthet Dent. 2018;119(4):593-599. https://doi.org/10.1016/j. prosdent.2017.06.012

14. Egbert JS, Johnson AC, Tantbirojn D, Versluis A. Fracture strength of ultrathin occlusal veneer restorations made from CAD/CAM composite or hybrid ceramic materials. Oral Sci Int. 2015;12(2):53-58. https://doi.org/10.1016/S13488643(15)00017-8

15. Swain MV, Coldea A, Bilkhair A, Guess PC. Interpenetrating network ceramic-resin composite dental restorative materials. Dent Mater. 2016;32(1):34-42. https://doi.org/10.1016/j. dental.2015.09.009 
16. Awada A, Nathanson D. Mechanical properties of resin-ceramic CAD/CAM restorative materials. J Prosthet Dent. 2015;114(4):587593. https://doi.org/10.1016/j.prosdent.2015.04.016

17. Yamaguchi S, Kani R, Kawakami K, Tsuji M, Inoue S, Lee C, et al. Fatigue behavior and crack initiation of CAD/CAM resin composite molar crowns. Dent Mater. 2018;34(10):15781584. https://doi.org/10.1016/j.dental.2018.07.002

18. Coldea A, Swain MV, Thiel N. Mechanical properties of polymer-infiltratedceramic-network materials. Dent Mater. 2013;29:419-26. https://doi.org/10.1016/j.dental.2013.01.002

19. Coldea A, Swain MV, Thiel N. In vitro strength degredation of dental ceramics and novel PICN material by sharp indentation. J Mech Behav Biomed Mater. 2013;26:34-42. https://doi. org/10.1016/j.jmbbm.2013.05.004

20. Albero A, Pascual A, Camps I, Grau-Benitez M. Comparative characterization of a novel cad-cam polymer-infiltratedceramic-network. J Clin Exp Dent. 2015;7(4):e495. https:// doi.org/10.4317/jced.52521

21. Egilmez F, Ergun G, Cekic-Nagas I, Vallittu PK, Lassila LVJ. Does artificial aging affect mechanical properties of CAD/ CAM composite materials. J Prosthodont Res. 2017;62(1):6574. https://doi.org/10.1016/j.jpor.2017.06.001.

22. Bradt RC, Evans AG, DPH H, Lange FF A. Fracture statics of multiple flaw distribution. New York: Plenum Press; 1983

23. Quinn JB, Quinn GD. A practical and systematic review of Weibull statistics for reporting strengths of dental materials. Dent Mater. 2010;2:135-47. https://doi.org/10.1016/j. dental.2009.09.006

24. Homaei E, Farhangdoost K, Tsoi JKH, Matinlinna JP, Pow EHN. Static and fatigue mechanical behavior of three dental CAD/ CAM ceramics. J Mech Behav Biomed Mater. 2016;59:304-313. https://doi.org/10.1016/j.jmbbm.2016.01.023

25. Lebon N, Tapie L, Vennat E, Mawussi B. Influence of CAD/ CAM tool and material on tool wear and roughness of dental prostheses after milling. J Prosthet Dent. 2015;114:236-47. https://doi.org/10.1016/j.prosdent.2014.12. 021

26. He LH, Purton D, Swain MV. A novel polymer infiltrated ceramic for dental stimulation. J Mater Sci Mater Med. 2011;22:1639-43. https://doi.org/10.1007/s10856-011-4350-3

27. Goujat A, Abouelleil H, Colon P, Jeannin C, Pradelle N, Seux $D$, et al. Mechanical properties and internal fit of 4 CAD-CAM block materials. J Prosthet Dent. 2018;119(3):384-389. https://doi.org/10.1016/j.prosdent.2017.03.001

28. Al-Akhali M, Chaar MS, Elsayed A, Samran A, Kern M. Fracture resistance of ceramic and polymer-based occlusal veneer restorations. J Mech Behav Biomed Mater. 2017;74:245-250. https://doi.org/10.1016/j.jmbbm.2017.06.013

29. Awad D, Stawarczyk B, Liebermann A, llie N. Translucency of esthetic dental restorative CAD/CAM materials and composite resins with respect to thickness and surface roughness. J Prosthet Dent. 2015;113(6):534-540. https:// doi.org/10.1016/j.prosdent.2014.12.003

30. Stöckl C, Hampe R, Stawarczyk B, Haerst M, Roos M. Macroand microtopographical examination and quantification of CAD-CAM composite resin 2-and 3-body wear. J
Prosthet Dent. 2018;120(4):537-545. https://doi.org/10.1016//. prosdent.2017.11.014

31. Mörmann WH, Stawarczyk B, Ender A, Sener B, Attin T, Mehl A. Wear characteristics of current aesthetic dental restorative CAD/CAM materials: two-body wear, gloss retention, roughness and Martens hardness. J Mech Behav Biomed Mater. 2013;20:113-125. https://doi.org/10.1016/j. jmbbm.2013.01.003

32. Zhi L, Bortolotto T, Krejci I. Comparative in vitro wear resistance of CAD/CAM composite resin and ceramic materials. J Prosthet Dent. 2016;115(2):199-202. https://doi. org/10.1016/j.prosdent.2015.07.011

33. Bollenl CM, Lambrechts $P$, Quirynen $M$. Comparison of surface roughness of oral hard materials to the threshold surface roughness for bacterial plaque retention: a review of the literature. Dent Mater. 1997;13(4):258-269. https://doi. org/10.1016/s0109-5641(97)80038-3

34. Jeong HY, Lee HH, Choi YS. Mechanical properties of hybrid computer-aided design/computer-aided manufacturing (CAD/CAM) materials after aging treatments. Ceramics Int. 2018;44(16):19217-19226. https://doi.org/10.1016/j. ceramint.2018.07.146

35. Hamza TA, Alameldin AA, Elkouedi AY, Wee AG. Effect of artificial accelerated aging on surface roughness and color stability of different ceramic restorations. Stomatological Dis Sci. 2017;1:8-13. https://doi.org/10.1016/j.jdent.2013.07.005

36. Druck CC, Pozzobon JL, Callegari GL, Dorneles LS, Valandro LF. Adhesion to Y-TZP ceramic: Study of silica nanofilm coating on the surface of Y-TZP. J Biomed Mater Res B Appl Biomater. 2015;103(1):143-150. https://doi.org/10.1002/jbm.b.33184

37. Flury S, Diebold E, Peutzfeldt A, Lussi A. Effect of artificial toothbrushing and water storage on surface roughness and micromechanical properties of tooth-colored CAD-CAM materials. J Prosthet Dent. 2017;117(6):767-774. https://doi. org/10.1016/j.prosdent.2016.08.034

38. Teixeira EC, Piascik JR, Stoner BR, Thompson JY. Dynamic fatigue and strength characterization of three ceramic materials. J Mater Sci Mater Med. 2007;18(6):1219-1224. https://doi.org/10.1007/s10856-007-0131-4

39. Aboushelib MN, Elsafi MH. Survival of resin infiltrated ceramics under influence of fatigue. Dent Mater. 2016; 32(4):529-534. https://doi.org/10.1016/j.dental.2015.12.001

40. Stawarczyk B, Sener B, Trottmann A, Roos M, Oezcan M, Haemmerle $\mathrm{C} \mathrm{H}$. Discoloration of manually fabricated resins and industrially fabricated CAD/CAM blocks versus glassceramic: effect of storage media, duration, and subsequent polishing. Dent Mater J. 2012;31(3):377-383. https://doi. org/10.4012/dmj.2011-238

41. Nobuaki A, Keiichi Y, Takashi S. Effects of air abrasion with alumina or glass beads on surface characteristics of CAD/ CAM composite materials and the bond strength of resin cements. J Appl Oral Sci. 2015;23(6):629-636. https://doi. org/10.1590/1678-775720150261

42. Lise DP, Van Ende A, De Munck J, Vieira L, Baratieri LN, Van Meerbeek B. Microtensile bond strength of composite cement to novel CAD/CAM materials as a function of surface 
treatment and aging. Oper Dent. 2017;42(1):73-81. https:// doi.org/10.2341/15-263-L

43. Peumans M, Valjakova EB, De Munck J, Mishevska CB, Van Meerbeek $B$. Bonding effectiveness of luting composites to different CAD/CAM materials. J Adhes Dent. 2016;18(4):289302. https://doi.org/10.3290/j.jad.a36155

44. Higashi M, Matsumoto M, Kawaguchi A, Miura J, Minamino $\mathrm{T}$, Kabetani $\mathrm{T}$, et al. Bonding effectiveness of self-adhesive and conventional-type adhesive resin cements to CAD/CAM resin blocks. Part 1: effects of sandblasting and silanization. Dent Mater J. 2016;35(1):21-28. https://doi.org/10.4012/ dmj.2015-234

45. Kassotakis EM, Stavridakis M, Bortolotto T, Ardu S, Krejci I. Evaluation of the effect of different surface treatments on luting CAD/CAM composite resin overlay workpieces. J Adhes Dent. 2015;17(6):521-528. https://doi.org/10.3290/j.jad.a35256

46. Frankenberger R, Hartmann VE, Krech M, Krämer N, Reich S, Braun A. Adhesive luting of new CAD/CAM materials. Int J Comput Dent. 2015;18(1):9-20.

47. Stawarczyk B, Krawczuk A, llie N. Tensile bond strength of resin composite repair in vitro using different surface preparation conditionings to an aged CAD/CAM resin nanoceramic. Clin Oral Investig. 2015;19(2):299-308. https://doi.org/10.1007/ s00784-014-1269-3
48. Elsaka SE. Bond strength of novel CAD/CAM restorative materials to self-adhesive resin cement: the effect of surface treatments. J Adhes Dent. 2014;16(6):531-540. https://doi. org/10.3290/j.jad.a33198

49. Kawaguchi A, Matsumoto M, Higashi M, Miura J, Minamino $T$, Kabetani T. Bonding effectiveness of self-adhesive and conventional-type adhesive resin cements to CAD/CAM resin blocks. Part 2: effect of ultrasonic and acid cleaning. Dent Mater J. 2016;35(1):29-36. https://doi.org/10.4012/ dmj.2015-235

50. Loomans BA, Cardoso MV, Opdam NJM, Roeters FJM, De Munck J, Huysmans MC, et al. Surface roughness of etched composite resin in light of composite repair. J Dent. 2011;39(7):499-505. https://doi.org/10.1016/.jdent.2011.04.007

51. Cekic-Nagas I, Ergun G, Egilmez F, Vallittu PK, Lassila LVJ. Micro-shear bond strength of different resin cements to ceramic/glass-polymer CAD-CAM block materials. J Prosthodont Res. 2016;60(4):265-273. https://doi.org/10.1016/j. jpor.2016.02.003

Received on: 11/9/2019

Final version resubmitted on: 27/11/2019 Approved on: 3/12/2019 